\title{
From leaf to flower: revisiting Goethe's concepts on the "metamorphosis" of plants
}

\author{
Marcelo Carnier Dornelas $^{1 *}$ and Odair Dornelas ${ }^{2}$
}

\begin{abstract}
${ }^{1}$ Departamento de Fisiologia Vegetal, Instituto de Biologia, Universidade Estadual de Campinas, CP 6109, 13084-971, Campinas, SP, Brazil; ${ }^{2}$ Universidade Federal de Mato Grosso do Sul, Campus de Três Lagoas, Av. Capitão Olinto Mancini, 1.662, CP 210, 79603-011 Três Lagoas, MS, Brazil; *Corresponding author: dornelas@unicamp.br
\end{abstract}

Received: 01/08/2005; Accepted: 10/12/2005

Goethe's seminal scientific work, Versuch die Metamorphose der Pflanzen zu erklaren (An Attempt to Interpret the Metamorphosis of Plants) dated from 1790, has created the foundations for many domains of modern plant biology. The archetypal leaf concept, which considers floral organs as modified leaves, besides being the best known has been proven true, following the description of the $\mathrm{ABC}$ molecular model of floral organ identity determination during the last decade. Here we analyze the whole theoretical frame of Goethe's 1790 publication and present two previously misconsidered aspects of this work: The "refinement of the sap" concept as a directional principle and the "cycles of contractions and expansions" as cycles of differential determination of the shoot apical meristem. The reinterpretation of these concepts are in line with the modern view that molecular networks integrate both environmental and endogenous cues and regulate plant development. This reassessment also helps to elaborate a theoretical frame that considers the evolutionary conservation of the molecular mechanisms that regulate plant development.

Key words: flower development, gene expression, Goethe, meristem behavior, theory of plant development

Da folha à flor: Revisitando os conceitos de Goethe sobre a "metamorfose" das plantas: O trabalho científico seminal de Goethe, Versuch die Metamorphose der Pflanzen zu erklaren (Uma Tentativa de Interpretação da Metamorfose das Plantas), datado de 1790, criou a fundação para muitos domínios da biologia vegetal moderna. O conceito do arquétipo foliar, que considera os órgãos florais como folhas modificadas, é o mais conhecido e provou ser verdadeiro após a descrição molecular do modelo $\mathrm{ABC}$ para a determinação da identidade dos órgãos florais durante a última década. Todo o aparato teórico desse trabalho de Goethe de 1790 é analisado aqui e dois aspectos previamente desconsiderados da obra são reinterpretados: O conceito de "purificação da seiva" como um princípio direcional e os "ciclos de contração e retração" como ciclos de determinação diferencial do meristema apical caulinar. A reinterpretação desses conceitos concorda com a visão moderna de que redes de interações moleculares integram sinais endógenos e ambientais e regulam o desenvolvimento vegetal. Esta reanálise auxilia ainda na formalização de um arcabouço teórico que considera a conservação evolutiva dos mecanismos moleculares que regulam o desenvolvimento vegetal.

Palavras-chave: comportamento meristemático, desenvolvimento floral, expressão gênica, Goethe, teoria do desenvolvimento de plantas.

\section{INTRODUCTION}

"The archetypal plant as I see, it will be the most wonderful creation in the whole world, and nature herself will envy me for it. With this model and the key to it, one will be able to invent plants (...) which, even if they do not actually exist, nevertheless might exist and which are not merely picturesque or poetic visions and illusions, but have inner truth and logic." (J.W. Goethe, in a letter of 1787 to the philosopher J. G. Herder, quoted in Mueller and Engard, 1952). 
One could think that the statement above was made by a less humble modern plant scientist talking about transgenics. But it was not. The great German poet Johann Wolfgang von Goethe, better known as the author of Faust and other enduring contributions to German literature, was also a lifelong student of nature, and his writings on scientific subjects fill several volumes. Goethe had been strongly interested in morphology throughout his life, and his preferences had always tended towards formalism, particularly towards the strongest version of the argument (and subject of this minireview): the vision of simple, generating archetypal forms, setting both the bounds and the possibilities of morphology.

Look carefully into any introductory botany textbook and you are likely to find a flower described as a shortened stem with four kinds of modified leaves: sepals, petals, stamens, and carpels. This simple concept, that floral parts are modified leaves, can be elaborated in various ways. In whatever form it appears, however, the idea is usually called the classical "foliar theory" of the flower. Effective formulation of a foliar theory began in 1790 when Goethe published his Versuch die Metamorphose der Pflanzen zu erklaren (An Attempt to Interpret the Metamorphosis of Plants). This work, little more than a pamphlet, consists of 123 numbered and almost aphoristic paragraphs. The original text in ancient German language can be easily found nowadays from many reliable sources on the Internet and a translation to English has been undertaken (Mueller and Engard, 1952). In this minireview we will quote Goethe's 1790 work, in our translation from the original, followed by the number of the paragraph quoted.

\section{Leaf as an archetype}

In his classical 1790 paper, Goethe applied to plants the same vision that Geoffroy Saint-Hilaire and Owen would later put forward in an attempt to reduce the great complexity and diversity of animal (or at least vertebrate) form to the single generating pattern of an archetypal vertebra (for the concepts of animal formalism see Raff, 1996; 2000). For Goethe, the leaf represented an archetypal form for all plant parts growing from the apical meristem (Goethe left out roots on purpose), from cotyledons, to stem leaves, to sepals, petals, pistils, stamens, and carpels (and also the fruit). Modern models of shoot and leaf development have constantly used this archetypic view of "leaf-shoot continuum" (Sinha, 1999). Nevertheless, the common epitome of Goethe's system, "all is leaf" should not be taken (too) literally as the actual reduction of all serial diversity to the actual form of a stem leaf. Such an interpretation would contravene the Platonic character of archetypes in formalist theory. The "leaf" represents an abstract generating principle, from which stem leaves depart least in actual expression. Goethe writes: "We ought to have a general term with which to designate this diversely metamorphosed organ and with which to compare all manifestations of its form (...) we might equally well say that a stamen is a contracted petal, as that a petal is a stamen in a state of expansion; or that a sepal is a contracted stem leaf approaching a certain stage of refinement, as that a stem leaf is a sepal expanded by the influx of cruder saps" (Goethe, 1790, No. 120). Goethe expressed the epitome of his system in his essay (Goethe, 1790, No. 119): "The organs of the vegetating and flowering plant, though seemingly dissimilar, all originate from a single organ, namely, the leaf". When parts become too distinct to show connection and reduction to the leaf archetype in one species, Goethe uses the comparative approach to find transitional forms in other taxa. The seedpod and sexual organs are manifestly "unleaflike" in many plants, but Goethe establishes transitional series to species with, for example, leaf-like seedpods, or fertile stem leaves (as in ferns, or cycads; figure 1). Consider his exposition of the comparative method for "difficult" seedpods: "Nature obscures the similarity to the leaf most when she makes the seed containers soft and juicy or firm or woody; however, the similarity will not escape our attention if we contrive to follow it in all its transitional stages" (Goethe, 1790, No. 79).

Almost two hundred years after Goethe published his work describing the leaf archetype, plant molecular biology and the field of evolutionary developmental biology (known as "evo-devo" or "evodevotics" to its practitioners, see Theissen et al., 2000), while still in its infancy, has invented the tools, and already produced a host of stunning and unexpected examples, for decoding the basic molecular structure of regulation, and for tracing the locations and timings of regulatory networks in the early development of complex multicellular creatures. The description of the simple and elegant "ABC" model for the determination of floral organ identity (Coen and Meyerowitz, 1991) and the discoveries of deep homology and conservation among the genes involved in the model, belonging to taxa that diverged some million years ago (for reviews see Theissen 2000; Irish and Litt, 2005), continue to accumulate at an accelerating pace, based on methodological refinements and extensions, in both speed and accuracy, that could hardly have been 
conceptualized little more than a decade ago. Much of our fascination with the data of evodevotics arises from the sheer novelty of discovery in biological domains that had been previously and totally inaccessible. Moreover, it illustrates the integrating power of scientific conclusions to translate much of Goethe's visions (and a previous descriptive botanical chaos) into explanatory causality.

Goethe's leaf archetype acquired its molecular explanation with the idealization of the "ABC" model (Coen and Meyerowitz, 1991; Theissen and Saedler 2001; Zahn et al., 2005). In this elegantly simple model (that is nevertheless under constant reformulation, see figure 2), based on genes with homeotic effects upon serially repeated structures arranged in systematic order (with repetition in concentric whorls rather than linearly along a body axis), $A$ genes operating alone determine the form of the outermost whorl of leaf-like sepals; $A$ plus $B$ genes regulate petals in the next whorl within; $B$ plus $C$, the formation of the male organs, the stamens, and finally the most interior female carpels. Functions D and $\mathrm{E}$ were added latter to adjust the model (see figure 2). When all $\mathrm{ABC}$ functions are depleted, the resulting formed organ is a "foliage" leaf (Coen and Meyerowitz, 1991; Weigel and Meyerowitz, 1994). Nevertheless, some carpel features may be sometimes retained in these "leaves", indicating that at least some redundancy may occur in the carpel determination pathway (Goto et al., 2001).

This model explains some of important issues on the evolution of plant development, ranging from the most theoretical (in "updating" Goethe's formalist theory that all parts regulated by the $\mathrm{ABC}$ series conform to a generalized "leaf" archetype), to the most practical (the manipulation of the $\mathrm{ABC}$ genes through transgenics would theoretically
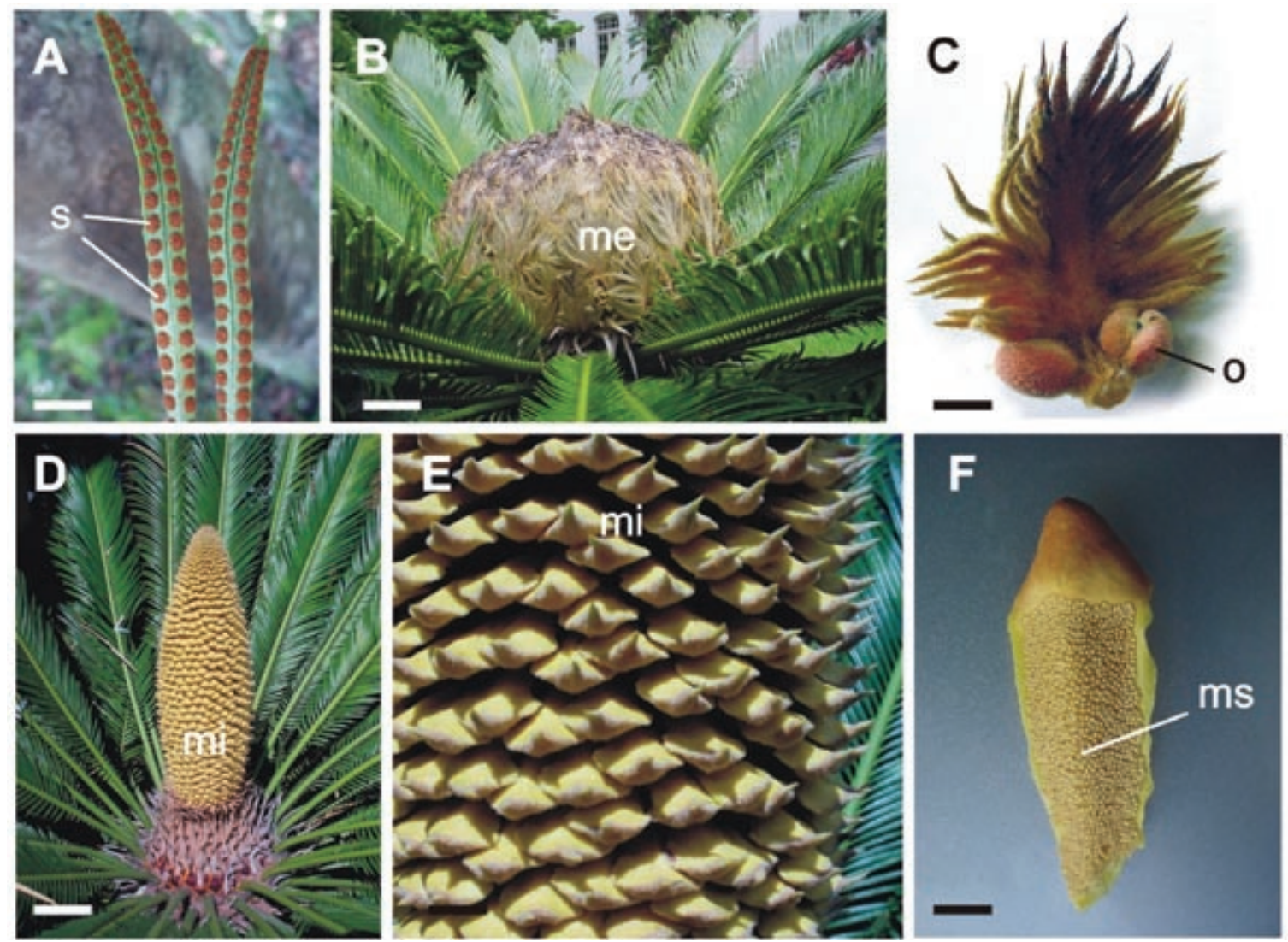

Figure 1. A. In ferns, clusters of sporangia (sori) containing spore mother cells are formed on the abaxial surface of fertile leaves. The fern leaves shown here are from genus Polypodium. B-F: Cycas revoluta. B. In the gymnosperm family Cycadaceae the fertile leaves of the female plant (megasporophylls) are loosely organized in a central cone. C. A single megasporophyll with naked ovules attached to its margin (stalk and additional ovules were cut away). D. The male plant with the male reproductive cone (microsporangiate strobilus). The modified leaves are smaller and more numerous than in female cones. E. Detail of the male cone. F. Each individual male fertile leaf (microsporophyll) has many microsporangia scattered over the lower surface. me: megasporophylls; mi: microsporophylls; ms: microsporangia; o: ovule; s: sori. Bars: A: $1 \mathrm{~cm} ; \mathbf{B}: 5 \mathrm{~cm}$; $\mathbf{C}$ and $\mathbf{E}: 1.5 \mathrm{~cm} ; \mathbf{D}: 7 \mathrm{~cm} ; \mathbf{F}: 0.7 \mathrm{~cm}$. 
allow the combination of any kind of floral organs in a same flower, e.g. see Dornelas, 2000).

If Goethe's system really advocated, as often misportrayed, a simple and exclusive concept of the archetypal leaf (e.g. see Coen, 2001), his theory could stake no claim for completeness, for this central principle cannot explain systematic variation in form up the stem, and therefore could not operate as a full explanation for both similarities and characteristic differences in the parts of plants. But, in his most fascinating intellectual move, Goethe proposes a

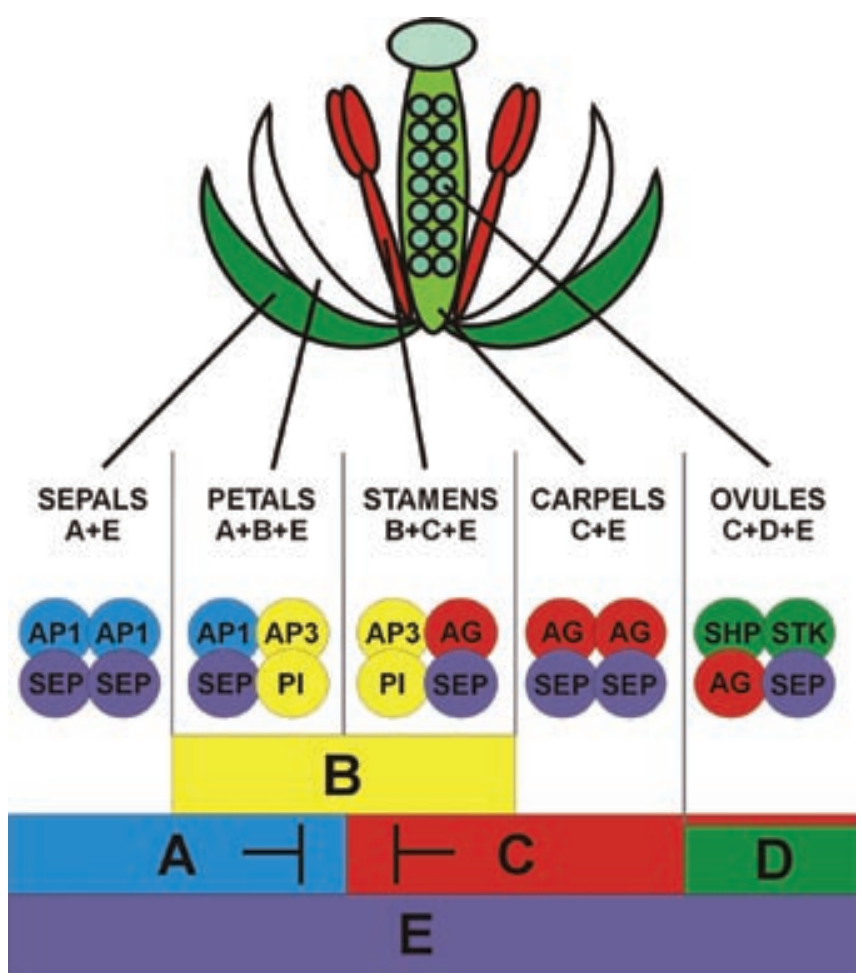

Figure 2. The revised $\mathrm{ABC}$ model of flower organ identity. A-function genes, (APETALA1 [API] in Arabidopsis) are necessary for the formation of the sepals, B-function genes (APETALA3 [AP3] and PISTILLATA [PI] in Arabidopsis), together with A-function genes, are necessary for the formation of the petals. The B-function genes, along with those of C-function (AGAMOUS [AG] in Arabidopsis), are necessary for the formation of the stamens, and $\mathrm{C}$-function genes alone are necessary for the formation of the carpels. The $\mathrm{ABC}$ model has been gradually expanded to include class D- and E-function genes, which are necessary for the ovules and the definition of the floral whorls, respectively. D-function genes in Arabidopsis include SEEDSTICK (STK) as well as SHATTERPROOF1 and SHATTERPROOF2 (SHP1 and SHP2). E-function sensu lato requires at least one of the four SEPALLATA (SEP1, SEP2, SEP3 and SEP4) genes (adapted from Theissen 2001; Theissen and Saedler 2001; Zahn et al., 2005). complete account by grafting two additional principles onto the underlying notion of archetype: the progressive refinement of sap, and cycles of expansion and contraction. We may regard these principles as ad hoc or incorrect today, but the power of their conjunction with the archetypal idea can be appreciated with much profit, with some re-interpretation. Goethe, faced with observations of both directionality and repeatability up the stem, recognized the need for both poles of this dichotomy.

\section{Goethe's “ refinement of sap" as a directional principle}

Up and down, heaven and hell, brain and psyche vs. bowels and excrement. Goethe, by no means immune the way of thinking in an age of Naturphilosophie, applied this major metaphorical apparatus of Western culture to plants as well, with gnarly roots and tubers as lowly objects of the ground, and fragrant, noble flowers as topmost parts, straining towards heaven. Goethe viewed the growth of a plant as progressing towards refinement from cotyledon to flower. He explained this directionality by postulating that, moving up the stem, each successive leaf modification progressively "filters" an initially crude sap. Inflorescence cannot occur until these impurities have been removed. The cotyledons begin both with minimal organization and refinement, and with maximal "crudity" of sap: "We have found that the cotyledons, which are produced in the enclosed seed coat and are filled to the brim, as it were, with a very crude sap, are scarcely organized and developed at all, or at best roughly so" (Goethe, 1790, No. 24). Finally, the plant achieves its topmost goal: "While the cruder fluids are in this manner continually drained off and replaced by pure ones, the plant, step by step, achieves the status prescribed by nature. We see the leaves finally reach their fullest expansion and elaboration, and soon thereafter we become aware of a new aspect, apprising us that the epoch we have been studying has drawn to a close and that a second is approaching, the epoch of the flower" (Goethe, 1790, No. 28).

From Goethe's statements, it is clear a perception that a directional principle applied to the modification of the general biochemical composition of the plant was necessary to achieve flowering. The interpretation of "purification of sap" as a directional principle has been missed by recent reviews on Goethe's botanical work (e.g. Schilperoord, 2005) that take the statement literally. Terms such "crude sap" were used merely due to a total lack of any molecular knowledge at the time. Goethe's directional principle can, nevertheless, be translated to the modern view that a series of 
gene products, most of them transcription factors, are in such genetic status (active or inactive, depending on whether it is an activator or a repressor) during embryonic and juvenile phases that flowering is inhibited (in Goethe's terms, the sap is "crude"). In response to environmental and endogenous factors, this genetic status is directionally re-programmed in order to allow the flowering process to occur (the sap is then directionally "purified").

One of the modern re-interpretations of Goethe's "refinement of sap" is the famous florigen concept, postulated by the Russian scientist Chailakhyan (1936). The florigen concept was more likely to prompt sarcastic grins than scientific inquiry (e.g. see Levy and Dean, 1998; Colasanti and Sundaresan, 2000) until being resuscitated recently by the astonishing discovery that a transcription factor, product of the CONSTANS (CO) gene, acts in the phloem, in response to photoperiodic stimulus to regulate a systemic signal which induces flowering of Arabidopsis plants (An et al., 2004). Surprisingly enough, CO-driven floral stimulation can be graft-transmitted (Ayre and Turgeon, 2004). CO mRNA accumulates under long-day conditions and oscillates in response to circadian rhythms (Suarez-Lopez et al., 2001). As may be expected for a gene that controls development in response to transient stimuli, both mRNA and protein accumulate to only very low levels (Suarez-Lopez et al., 2001) and thus have been undetected by most techniques during all these years. Accordingly, Arabidopsis co mutants are late-flowering and the overexpression of $C O$ by transgenic Arabidopsis plants caused the expected earlyflowering phenotype (Putterill et al., 1995; Suarez-Lopez et al., 2001; Ayre and Turgeon, 2004). More interesting, CO putative orthologs were found in many other plant species with diverse photoperiodic demands, including grasses and legumes (Dornelas and Rodriguez 2004, 2005; Hecht et al., 2005), suggesting that CO-driven flowering stimulation may be evolutionary conserved.

According to Goethe, the plant then grows towards a floral apotheosis, but too much nutriment delays the process of filtering sap, as material rushes in and more stem leaves must be produced for drainage. A decline in nutriment finally allows filtering to attain the upper hand, and the sap becomes sufficiently pure for inflorescence: "As long as cruder saps remain in the plant, all possible plant organs are compelled to become instruments for draining them off. If excessive nutriment forces its way in, the draining operation must be repeated again and again, rendering inflorescence almost impossible. If the plant is deprived of nourishment, this operation of nature is facilitated" (Goethe, 1790, No. 30). This another aspect of Goethe's perception, that the flowering process can be modulated by nutrition, is well known to occur at the molecular level (Corbesier et al., 1998). And more revealing is the fact that the nutrient-regulated pathway and the CO-regulated pathway converge into the product of the $L E A F Y$ gene, which is a central integrator of the flowering pathways (Ohto et al., 2001).

An interesting combination of both Goethe's concepts of leaf archetype and directional principle can be used to explain the progressive transition of floral organs in basal angiosperm taxa such as Magnolia and Nymphaea (figure 3). In these taxa, the arrangement of reproductive organs follows a spiral phyllotaxy and not a whorled distribution and thus, an exception to the strict $\mathrm{ABC}$ model kind of gene expression is to be expected (Kim et al., 2005). Additionally, there is a smooth transition among floral organ identity as among petals and stamens, for example, are intermediate organs with petaloid identity bearing pollen sacs (figure 3). This spiral arrangement of floral organs is genetically controlled and considered to be the retention of an ancestral character and reminiscent of gymnosperm strobili (Baum, 1998; He et al., 2004). The molecular mechanism underlying phyllotaxy control is being unraveled and helical arrangement of floral organs can be induced in genetically manipulated Arabidopsis plants, which would normally produce whorledarranged floral organs (Hashimoto, 2002).

\section{Cycles of expansion and contraction}

As a final addition to the theoretical body of his "Metamorphose der Pflanzen" Goethe includes a cyclical force, in opposition to the directional principle of "refining sap". He envisages three full cycles of contraction and expansion during plant ontogeny. The interplay of these progressive and cyclical forces produces the full pattern of a general refinement up the stem, but impacted by discontinuities and transitions that express no directional pattern ("contraction" of stem-leaves to sepals by bunching them together in a whorl, for example).

The cotyledons begin in a retracted state. The main leaves, and their substantial spacing on the stem, represent the first expansion. The bunching of leaves to form the sepals at the base of the flower marks the second contraction, and the subsequent elaboration of petals the second expansion. The reduction of archetypal leaf size to form pistils and stamens marks the third contraction, and the formation of fruit the last and most exuberant expansion. The contracted 
seed within the fruit then starts the cycle again in the next generation: "Whether the plant vegetates, blossoms, or bears fruit, it nevertheless is always the same organs with varying functions and with frequent changes in form, that fulfill the dictates of Nature. The same organ which expanded on the stem as a leaf and assumed a highly diverse form, will contract in the calyx, expand again in the petal, contract in the reproductive organs, and expand for the last time as fruit" (Goethe 1790, No. 115).

Plant apical meristems are gradually patterned during embryogenesis (Long and Barton, 1998), culminating in the formation of a highly organized structure with overlapping functional domains (for a review see Sharma et al., 2003). The self-renewing stem cell niche is confined to the most apical, central portion of the meristem. Mitotic cell divisions in this region, which is called the central zone, causes displacement of daughter cells outward into the peripheral region (figure 4). These more rapidly dividing peripheral zone cells undergo differentiation and become incorporated into organ primordia on the meristem flanks. This model of meristem structure and functioning has been recently validated by in vivo analysis of meristem behavior (Grandjean et al., 2004). Thus, Goethe was correct to affirm that the "first expansion" occurs at the transition of a contracted embryonic (mostly inactive) apical meristem state to a post-embryonic active state, as the elaboration of plant architecture by the shoot meristem occurs mainly post-embryonically (Simon, 2001).

Following germination, the shoot apical meristem generates an indeterminate number of leaf primordia, which may bear axillary shoot meristems. During the


Figure 3. Spirally-arranged floral organs in basal angiosperms. A: Magnolia watsoniana. B: Nymphaea caerulea; C: Nymphaea gigatea var. Perry's Baby; D: Nymphaea odorata. Note the gradual transition between petals and stamens with intermediate petaloid structures containing pollen grains. Bars: A-C: $1.5 \mathrm{~cm}$; D: $600 \mu \mathrm{m}$. 
switch to reproductive development, the vegetative meristems are commonly converted into indeterminate inflorescence meristems (Ratcliffe et al., 1999). The product of inflorescence meristems are generally determined floral meristems, which in turn produce floral organs, which are, by definition, determinate structures. If we consider Goethe's concept of "expansion" and "contraction" in terms of changing the determinacy behavior of the shoot apical meristem than, again, his formalist perception is mostly in accord to the actual modern interpretation of plant organ ontogenesis.

Growth and differentiation within the meristem structure must be coordinated to maintain meristem shape and produce normal organs. This implies that meristem cells exchange signals to coordinate their behavior, directing the two meristem functions: cell proliferation and organ initiation (Traas and Vernoux, 2002). Only recently the molecular nature of the regulatory system controlling meristem behavior began to be unraveled (Dornelas et al., 2000; Haecker and Laux, 2001; Lohman et al., 2001; Castellano and Sablowski, 2005). If the activity of floral meristem identity genes is reduced, flowers will develop with various shootlike characteristics (Ratcliffe et al., 1999). In extreme cases, such as the leafy/apetalal/cauliflower Arabidopsis triple mutant, inflorescence nodes comprise secondary shoots with subtending leaves, and flowers are rarely produced (Bowman et al., 1993). Thus, these observations are an exemplar case of a failure to perform the first Goethian meristem "contraction", or the conversion of indeterminate, spirally arranged inflorescence meristems into determinate, whorled floral meristems. The maintenance of the whorled state by the production of additional floral organs may be viewed as the second round of a Goethian meristem "expansion". The second "contraction" cycle is perfectly exemplified by the role of the $C$-function Arabidopsis gene AGAMOUS. Besides being a $C$-function gene (see the first section of this review), AG also limits proliferation of floral stem cells (Lohman et al., 2001). While a central pool of stem cells replenishes the indeterminate shoot meristem, this pool is only transiently maintained in determinate floral meristems, which therefore stop producing new organs after the carpels have differentiated. Accordingly, in Arabidopsis ag mutants, organ formation does not terminate with the formation of fourth-whorl organs, but continues indeterminately. Contrastingly, the main shoot of Arabidopsis wuschel (wus) mutants terminates after producing only a few leaves (Mayer et al., 1998). A molecular link thus exists between stem cell regulation and meristem patterning in plants (figure 4). The size of WUS-dependent stem cell population is regulated through a negative feedback loop in which WUS induces the expression of the CLAVATA (CLV) gene system, which in turn, limits the WUS expression domain (Brandt et al., 2000; Schoof et al., 2000; Lohman et al., 2001). When the domains of either WUS or CLV3 expression are expanded or contracted, the meristem size and behavior in transgenic plants respond accordingly (Schoof et al., 2000; Lohman et al., 2001). In other terms, cycles of "expansion" and "contraction" of gene expression domains characterize the meristem behavior during all plant life cycle.

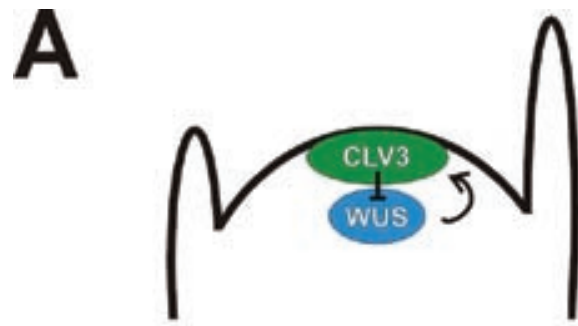

B
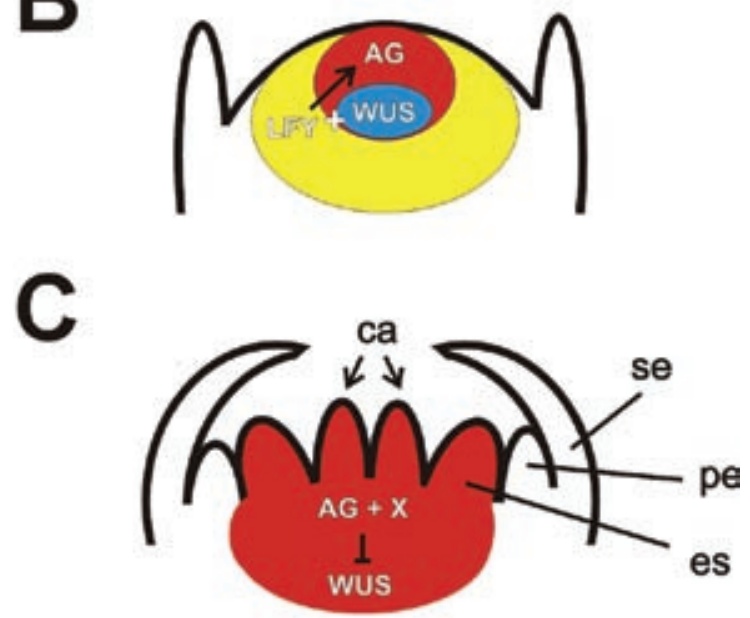

Figure 4. Molecular model of the feedback loop regulating stem cell determination in Arabidopsis. A: Schematic representation of an indeterminate vegetative apical meristem, showing the interaction between CLV3 and WUS in their respective domains. In the vegetative meristem, $L F Y$ is normally absent and $A G$ expression is not induced. B: In early floral meristems, $L F Y$ begins to be expressed and acts together with WUS to induce $A G$ transcription in the center of the developing flower. $\mathbf{C}$ : At the time of carpel initiation, $A G$ and an additional, as yet unidentified factor (X) repress WUS expression to terminate stem cell activity and make the meristem determinate. ca: carpel primordia; es: stamen primordium; pe: petal primordium; se: sepal primordium. 


\section{Conclusions}

Put Goethe's three formative principles together (the archetypal leaf, progressive refinement of sap up the stem, and three expansion-contraction cycles of meristem behavior) and the vast botanical diversity of our planet falls under the chief vision of formalism: production of a final form from interaction of a few abstract, general, and internally based (not externally imposed and adaptationally driven) morphological laws. Therefore, a final word must be said about Goethe's formalism: in classical formalist or structuralist theories, the strongest correlation unites a commitment to generative laws of form with an aversion to adaptationist explanation as the primary goal of morphology. Obviously, such ideas would make Darwin tremble into his grave. For Darwin, discontinuity originates by historical contingency (following extinction of intermediate forms) in a fully accessible and isotropic morphospace. Natura non facit saltum. But the universe of formalism, in ideas and in morphology, views discontinuity as inherent in the structure of inhabitable space.

It is, by no means, our intention to reject any consolidated evolutionary concept, nevertheless almost every formalist theory of morphology views adaptation as secondary tinkering rather than primary structuring. Although the principle of "genetic tinkering" has long been absorbed into the evolutionary theory (Monod, 1970; Jacob, 1977), some implications of Goethe's formalism to the study of morphological evolution has only recently been appreciated (Coen, 2001). The final marriage between formalism and functionalism with the blessings of an evolutionary frame has been achieved by the modern synthesis of the evolutionary theory (e.g. see Stebbins, 1974). Nevertheless, questions regarding the origin of body plans, and the evolutionary constrains imposed by the molecular mechanisms underlying development, both in animals and in plants, remain largely unanswered (Gould, 2002). Additionally, novel ideas of selfassembling of complex systems (including the biological ones), sounding quite "neo-formalists" are more and more discussed among biology scientists (e.g. see Solé et al., 2003).

We expect that our re-interpretation of Goethe's 1790 work, which brings the proposition of two novel conceptual principia, might collaborate with the elaboration of a theoretical frame that congregates the recent advances on the field of evolutionary and molecular developmental plant biology.
Acknowledgments: To MCD's mom and OD's wife, who happens to be the same person, Lucy MC Dornelas, for keeping the appetizers flowing during the most pleasant nights of March 2005 when our ideas about Goethe were bubbling. FAPESP supports most of MCD's research in plant development.

\section{REFERENCES}

An H, Roussot C, Suárez-López P, Corbesier L, Vincent C, Piñeiro M, Hepworth S, Mouradov A, Justin S, Turnbull C, Coupland G (2004) CONSTANS acts in the phloem to regulate a systemic signal that induces photoperiodic flowering of Arabidopsis. Development 131:3615-3626.

Ayre BG, Turgeon R (2004) Graft transmission of a floral stimulant derived from CONSTANS. Plant Physiol. 135: 2271-2278.

Baum, DA (1998) The evolution of plant development. Curr. Opin. Plant Biol. 1:79-86.

Brand U, Fletcher JC, Hobe M, Meyerowitz EM, Simon R (2000) Dependence of stem cell fate in Arabidopsis on a feedback loop regulated by CLV3 activity. Science 289: 617-619.

Castellano MM, Sablowski R (2005) Intercellular signaling in the transition from stem cells to organogenesis in meristems. Curr. Opin. Plant Biol. 8:26-31.

Chailakhyan MK (1936) On the hormonal theory of plant development. Dokl. Akad. Nauk 3:452.

Coen E (2001) Goethe and the ABC model of flower development. Comp. R. Acad. Sci. Paris 324:1-8.

Coen ES, Meyerowitz EM (1991) The war of the whorls: genetic inter-actions controlling flower development. Nature 353:31-37.

Colasanti J, Sundaresan V (2000) 'Florigen' enters the molecular age: long-distance signals that cause plants to flower. Trends Biochem. Sci. 25: 236-240.

Corbesier L, Lejeune P, Bernier G (1998) The role of carbohydrates in the induction of flowering in Arabidopsis thaliana: comparison between the wild type and a starchless mutant. Planta 206:131-137.

Dornelas MC (2000) Construindo flores: O controle molecular da arquitetura floral. Biotecnol. Ciênc. Desenvolv. 12: 44-46.

Dornelas MC, van Lammeren AAM, Kreis, M (2000) Arabidopsis thaliana SHAGGY-related protein kinases (AtSK11 and 12) function in perianth and gynoecium development. Plant J. 21:419-429.

Dornelas MC, Rodriguez, APM (2004) Identification of differentially expressed genes during reproductive development in sugarcane (Saccharum sp) by the analysis of expressed sequence tags. Flowering Newslett. 37:40-45.

Dornelas MC, Rodriguez, APM (2005) Identifying Eucalyptus expressed sequence tags related to Arabidopsis floweringtime pathway genes. Braz. J. Plant Physiol. 17:255-266.

Goethe JW von (1790) Versuch die Metamorphose der Pflanzen zu erklaren. Gotha, Ettlinger. 
Goto K, Kyozuka J, Bowman JL (2001) Turning floral organs into leaves, leaves into floral organs. Curr. Opin. Gen. Dev. 11:449-456.

Gould SJ (2002) The Structure of Evolutionary Theory. Belknap Press, Cambridge.

Grandjean O, Vernoux T, Laufs P, Belcram K, Mizukami Y, Traas J (2004) In vivo analysis of cell division, cell growth, and differentiation at the shoot apical meristem in Arabidopsis. Plant Cell 16:74-87.

Haecker a, Laux T (2001) Cell-cell signaling in the shoot meristem. Curr. Opin. Plant Biol. 4:441-446.

Hashimoto T (2002) Molecular genetic analysis of left-right handedness in plants. Phil. Trans. R. Soc. Lond. B 357: 799-808.

He C, Münster T, Saedler H (2004) On the origin of floral morphological novelties. FEBS Lett. 567:147-151.

Hecht V, Foucher F, Ferrandiz C, Macknight R, Navarro C, Morin J, Vardy ME, Ellis N, Beltran JP, Rameau C, Weller JL (2005) Conservation of Arabidopsis flowering genes in model legumes. Plant Physiol. 137:1420-34.

Irish VF, Litt A (2005) Flower development and evolution: gene duplication, diversification and redeployment. Curr. Opin. Gen. Dev. 15:1-7.

Jacob F (1977) Evolution as tinkering. Science 196:11611166.

Kim S, Koh J, Yoo MJ, Kong H, Hu Y, Ma H, Soltis PS, Soltis DE (2005) Expression of floral MADS-box genes in basal angiosperms: implications for the evolution of floral regulators. Plant J. 43:724-744.

Levy YY, Dean C (1998) The transition to flowering. Plant Cell 10:1973-1989.

Lohmann JU, Hong RL, Hobe M, Busch MA, Parcy F, Simon R, Weigel D (2001) A molecular link between stem cell regulation and floral patterning in Arabidopsis. Cell 1056:793-803.

Long JA, Barton MK (1998) The development of apical embryonic pattern in Arabidopsis. Development 125:30273035.

Mayer KFX, Schoof H, Haecker A, Lenhard M, Jürgens G, Laux T (1998) Role of WUSCHEL in regulating stem cell fate in the Arabidopsis shoot meristem. Cell 95:805-815.

Monod J. (1970) Le hasard et la nécessité , Editions du Seuil, Paris.

Mueller B, Engard CJ (1952) Goethe's Botanical Writings. University oh Hawaii Press, Honolulu.

Putterill J, Robson F, Lee K, Simon R, Coupland G (1995) The CONSTANS gene of Arabidopsis promotes flowering and encodes a protein showing similarities to zinc finger transcription factors. Cell 80:847-857.

Ohto M, Onai K, Furukawa Y, Aoki E, Araki T, Nakamura K (2001) Effects of sugar on vegetative development and floral transition in Arabidopsis. Plant Physiol. 127:252-261.
Raff RA (1996) The shape of life: Genes, development and the evolution of animal form. University of Chicago Press, Chicago.

Raff RA (2000) Evo-devo: the evolution of a new discipline. Nature Rev. Gen. 1:74-79.

Ratcliffe OJ, Bradley DJ, Coen ES (1999) Separation of shoot and floral identity in Arabidopsis. Development 126:11091120 .

Schilperoord P (2005) Modelling the plan, Goethe and molecular genetics. In: Harlan, V. (ed) Wert und Grenzen des Typus in der botanischen Morphologie, pp.217-232. Nümbrecht, Martina-Galunder-Verlag.

Schoof H, Lenhard M, Haecker A, Mayer KFX, Jürgens G, Laux T (2000) The stem cell population of Arabidopsis shoot meristems is maintained by a regulatory loop between the CLAVATA and WUSCHEL genes. Cell 100:635-644.

Sharma VK, Carles C, Fletcher JC (2003) Maintenance of stem cell populations in plants. Proc. Natl. Acad. Sci. USA 100:11823-11829.

Simon R (2001) Function of plant shoot meristems. Cell Dev. Biol. 12:357-362.

Sinha N (1999) Leaf development in angiosperms. Ann. Rev. Plant Physiol. Plant Mol. Biol. 50:419-446.

Stebbins GL (1974) Flowering plants. Evolution above the species level. The Belkamp Press of Harvard University Press, Cambridge.

Solé RV, Fernandez P, Kauffman S (2003) Adaptive walks in a gene network model of morphogenesis: insights into the Cambrian explosion. Int. J. Dev. Biol. 47:693-701.

Suarez-Lopez P, Wheatley K, Robson F, Onouchi H, Valverde F, Coupland G (2001) CONSTANS mediates between the circadian clock and the control of flowering in Arabidopsis. Nature 410:1116-1120.

Theissen G (2000) Evolutionary developmental genetics of floral symmetry: the revealing power of Linnaeus' monstrous flower. Bioessays 22:209-213.

Theissen G, Becker A, Di Rosa A, Kanno A, Kim JT, Munster T, Winter KU, Saedler H. (2000) A short history of MADSbox genes in plants. Plant Mol. Biol. 42:115-149.

Theissen G, Saedler H. (2001) Plant Biology: Floral Quartets. Nature 409:469-471

Traas J, Vernoux T (2002) The shoot apical meristem: the dynamics of a stable structure Phil. Trans. R. Soc. Lond. B 357:737-747.

Weigel D, Meyerowitz EM (1994) The ABCs of floral homeotic genes. Cell 78:203-209.

Zahn LM, Leebens-Mack J, DePamphilis CW, Ma H, Theissen G (2005) To B or Not to B a flower: the role of DEFICIENS and GLOBOSA orthologs in the evolution of the angiosperms. J. Hered. 96:225-240. 